\title{
Surfaces
}

\section{The Work of Women's Studies Roundtable 1}

\section{Rachel Bowlby}

Volume 7, 1997

\section{LE FÉMINISME HORS DE LUI-MÊME}

FEMINISM BESIDE ITSELF

URI : https://id.erudit.org/iderudit/1064803ar

DOI : https://doi.org/10.7202/1064803ar

Aller au sommaire du numéro

Éditeur(s)

Les Presses de l’Université de Montréal

ISSN

1188-2492 (imprimé)

1200-5320 (numérique)

Découvrir la revue

Citer cet article

Bowlby, R. (1997). The Work of Women's Studies: Roundtable 1. Surfaces, 7.

https://doi.org/10.7202/1064803ar d'utilisation que vous pouvez consulter en ligne. 


\section{The Work of Women's Studies \\ Roundtable 1}

Rachel Bowlby

University of Sussex

Surfaces Vol. VII.104 (v.1.0A - 24/06/1997) - ISSN:

1188-2492

Copyright for texts published in Surfaces remains the property of authors. However, any further publication should be accompanied by an acknowledgement of Surfaces as the place of initial publication.

Asked to speak about "Feminism and the Future of Women's Studies," my mind, I confess, was blank. Too big, too much, too grand. Define feminism, define women's studies, define "the" future... I feel something in the heading calling on me to be either predictive or utopian, yet somehow-but why?-neither mode seems at all the right one, for now, for this conference, for me. Now if it had been "Generational Anxieties"-no problem. "Erotic Politics"? "Body Stuff"? I could say a little bit about that.

Tomorrow, at the end, there's "The Futures of Feminism?"-the open plural and open question. But at the beginning, to set the tone, we are meant, it might seem, to be on firmer ground, all the better to move away from it over the next two days. I can't help feeling we've been put on as the warm-up routine. Or maybe we've been set a kind of "hardy perennial" question, one that just pops up year after year, tough as ever, changing a bit with age and with the soil and the climate, figuring unobtrusively in the background of the scene? Well, fair enough. Let me try to begin in that mode. I am a good and willing feminist citizen, I hope. I will begin with a few schematic and largely imaginary oppositions. 
Feminism and women's studies. Feminism as the movement, the agitation, women's studies as the settlement. Feminism as the street, women's studies as the libraries and the seminar rooms. Feminism as the future, a hope or a grievance and an aim. Women's studies as the continuous present, the day-to-day rhythm and annual cycles-a routine of academic life.

Two views of the relationship. First, feminism with women's studies. Here, women's studies appears as a continuation or manifestation of feminism, validating and formalising its right to exist and develop and have an acknowledged identity within institutional and other contexts. Or, feminism versus women's studies. The development of women's studies is thought to mark an end of another kind to feminism, signifying negatively its entry into, and assimilation with, those structures and conventions of society that it had once set out to contest.

Those two perspectives persist, I think, in various forms, even as they also seem out of date, to belong at a time when feminism was young, rash and radical-and women's studies could either look the same (the continuation model) or else be seen as the fatal loss of impetus implied by any form of accommodation with the status quo. Nowadays, from either of these perspectives, women's studies may well appear as a relatively fixed accommodation, reasonably comfortable. Housed, perhaps, in a slightly quaint old building on the edge of campus, with calming, pale lemon wallpaper, or perhaps even in a set of new seminar rooms and offices in a recently built block. Now, when feminism is in some quarters at least about getting professional power and money for yourself, and women's studies is well accepted in numerous institutions, often with its own history stretching back twenty years, and when it looks very much like the sage older sister in comparison to the sexier other studies that have set themselves up alongside, the issue might not seem quite so pressing.

Then, there is the matter of language, which seems to fix a difference between the two to the clear disadvantage of women's studies. "Feminism" easily becomes "feminist" and is ready to attach itself to anything and anyone with adjectival abandon-feminist this, feminist that, and especially feminist the other. But what can you do with women's studies? It's stuck in a nominal rut, a rather ungainly collective noun that even includes an unwieldy possessive as part of its fixed constitution. And then, at a certain point in the history, "feminist" could maintain an agile theoretical flexibility, while the women 
in women's studies appear as cumbersomely essentialist bodies that refuse to be dislodged.

In one sense, the relationships between feminism and women's studies go back only as far as the names-which in the case of women's studies must be no more than twenty-some years. But it might be that elements of a prehistory might shift the focus away from the set divisions I've described; that in my case, thinking back through Woolf might be a way of trying to think forwards in the futures of feminism and women's studies. A Room of One's Own, as it happens, itself begins with an apology for not answering a large feminist questionabout women and fiction-or rather, by answering it only obliquely, with a seemingly small and local answer: the room of one's own. Perhaps this impossibility of supplying a complete or direct answer to the big question is somehow structurally inherent in the erratic development of feminism, what puts it always beside itself, digressive, with more than one direction and no fixed abode. As in so many other ways, this text written in 1928 appears, in the light of subsequent feminist history, to have been prophetic as well as hopeful about the development of what we would now call women's studies.

At numerous points, Woolf stops to make recommendations to her hypothetical audience of women undergraduates at Cambridge, for research projects to be undertaken, by women, about women or about what has made women what they are. For instance-on women's history as the data of social history and everyday life:

What one wants, I thought-and why does not some brilliant student at Newnham or Girton supply it?-is a mass of information;... All these facts lie somewhere, presumably, in parish registers and account books; the life of the average Elizabethan woman must be scattered about somewhere.[ $\underline{\mathbf{1}}$ ]

On women's labor history and the lives of ordinary women: "And there is the girl behind the counter too-I would as soon have her true history as the hundred and fiftieth life of Napoleon or seventieth study of Keats and his use of Miltonic inversion" (86). On conditions at once social and psychological affecting women's artistic production or the lack of it-"Here the psychologists of Newnham and Girton might come to our help, I thought, looking again at the blank spaces on the shelves. For surely it is time that the effect of discouragement on the 
mind of the artist should be measured" (51). On women's psychology more generally: "And yet, I continued, approaching the bookcase again, where shall I find that elaborate study of the psychology of women by a woman?" (75). On masculinity: "the history of men's opposition to women's emancipation is more interesting perhaps than the story of that emancipation itself. An amusing book might be made of it if some young student at Girton or Newnham would collect examples and deduce a theory" (54). On masculinity again: "these contributions to the dangerous and fascinating subject of the psychology of the other sex-it is one, I hope, that you will investigate when you have five hundred a year of your own" (36-7). And yet again: "That profoundly interesting subject, the value that men set upon women's chastity and its effect upon their education, here suggests itself for discussion, and might provide an interesting book if any student at Girton or Newnham cared to go into the matter" (61-2). After Woolf has awarded grants to all these projects, there is finally the grand and general call to women to write anything:

Therefore I would ask you to write all kinds of books, hesitating at no subject however trivial or however vast... You would write books of travel and adventure, and reserarch and scholarship, and history and biography, and criticism and philosophy and science. (103-4)

The room of one's own with five hundred a year can well seem, in this light, to be a forerunner of those rooms of our own, more or less adequately resourced, that are women's studies.

Such projects, as Woolf says, are no neutral addition to the existing corpus of knowledge; they will "rewrite history," in her own phrase, even as they transform the future of women, by showing up the past in a different and unrecognisable light. It is this kind of displacement and illumination, shifting the connections and directions between past, present and future, which is also envisaged in the famous passage about the supposed story of Chloe and Olivia in a recently written novel:

For if Chloe likes Olivia and Mary Carmichael knows how to express it she will light a torch in that vast chamber where nobody has yet been. It is all half lights and profound shadows... (80)

Here the feminist future is imagined as the opening of a new and unknown space-a "chamber"-that will then, so it 
is implied, have altered the topography of all the existing, familiar spaces.

Chloe and Olivia appear in a deliberately ambiguous place that moves between the sexual, the sisterly and the professional. "'Chloe liked Olivia.' Do not blush. Let us admit in the privacy of our own society that these things sometimes happen. Sometimes women do like women" (78). But further on: "Also, I continued, looking down at the page again, it is becoming evident that women, like men, have other interests besides the perennial interests of domesticity. 'Chloe liked Olivia. They shared a laboratory together...'"-which, Woolf says subsequently, "will make their friendship more varied and lasting because it will be less personal."

With Chloe and Olivia, the room of one's own opens out into two new spaces of very different kinds-the lab and the "vast chamber." That double space is at once personal and professional, erotic and impersonal, a space of either love or work, or both, or the clash between the two: the personal, and-as Woolf dubs it, positively-the "less personal." The uses and pleasures of a room of one's own seem simple and obvious enough. But it has never been so clear where women's studies, those plural and indefinite places, begin and end, where and when we are in them or not. It is as though we had moved, through feminism, as feminists, from the private possibilities and limitations of isolated individuals, to the plural and institutional advantages and constraints of women's studies. From a room of one's own to rooms or studies of our own.

When Woolf wrote, "professions for women," though a primary topic of feminist concern, had barely begun to be a real possibility-even by law in most instances in Britain, let alone in practice. Her piece of that name is about female sexuality, the rejection of domesticity and the murder of bad mothers more than it is about offices or laboratories or degree-awarding institutions. Yet today, in women's studies, the spaces, the studies, that we inhabit blur the boundaries between the professional and the emotional, between public and private worlds. There remain few of the older, recognisable divisions of labour and love, or of work and home (Chloe and Olivia's separate, and gendered spheres of domesticity and laboratory).

Now, in 1995, Chloe and Olivia are no doubt doing what they do by e-mail. Their studies are not tidy. (Who ever heard the phrase "I'm just going to clear my desk" 
spoken by a woman?) The future of women's studies, in which "no subject however trivial" is off the agenda, is a messy one. Women's work. Never done.

\section{NOTES}

1. Virginia Woolf, A Room of One's Own (1929; rpt. London: Granada), p. 44. All further page references will appear within the main text.

Accueil Surfaces | Table des matières | Recherche Surfaces Home Page | Table of Contents | Search

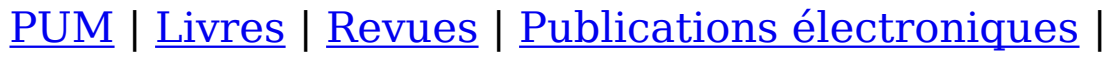
Vente et distribution 